Turkish Online Journal of Qualitative Inquiry (TOJQI)

Volume 11, Issue 3, July 2020: 417-435

DOI: $10.17569 /$ tojqi.641786

Research Article

\title{
Views of Prospective Teachers and Supervisors on a Practicum Program: A Case Study ${ }^{12}$
}

\author{
Görsev Sönmez Boran ${ }^{3}$
}

\begin{abstract}
Practicing what has been learned throughout the teacher education programs in Turkey is accepted as the end point of the preservice teaching career. This period of practice teaching serves as the time to implement theory into practice under the supervision of faculty members. In this study, the major purpose was to investigate the views of supervisors and preservice teachers regarding the practice teaching program which was redesigned to overcome some limitations of the current one. As a second purpose, the commonalities and differences between the self-reflections of preservice teachers and feedback provided by the supervisors on a specific practice teaching session in the final term were also investigated. To gather data, six preservice teachers majoring in language teaching and two faculty members were assigned to respond to two different written guidelines provided with these purposes. Written responses were analyzed through content analysis and open-coding. Results showed that both preservice teachers and supervisors think that redesigned program has many strengths such as time allocated to practice and feedback sessions. However, they also believe that, active practice teaching only in the final year is the weakness of this new program. The analysis of the written documents after the practice teaching of prospective teachers showed that prospective teachers gained a great reflective

\footnotetext{
${ }^{1}$ The ethical committee permission is not required in this study since the data were gathered before 2020 .

2 The initial findings of the study were presented at the " 2019 ITEAC III. International Teacher Education and Accreditation" held in Ankara (Turkey) on $30^{\text {th }}$ of November- ${ }^{\text {st }}$ of December 2019.

3 Assist.Prof.Dr., Biruni University, Faculty of Education, Department of Foreign Languages Teaching, gorsevi@gmail.com, https://orcid.org/0000-0001-6726-3452.
}

Received: 02.11.2019, Accepted: 24.07.2020 
perspective throughout their education. There are also some differences in their reflections and feedback from supervisors about the use of materials, planning and use of methods. This study has specific implications for language teacher education programs and teacher trainers.

Keywords: Practice teaching, prospective teachers, supervisors, teacher education 


\title{
Öğretmen Adaylarının ve Gözetmenlerin Uygulama Öğretimi Programına İlişkin Görüşlerinin İncelenmesi: Bir Durum Çalışması
}

\begin{abstract}
$\ddot{O} z$
Türkiye'deki öğretmen yetiştirme programlarında öğrenilenleri uygulamak, öğretmen adaylığ kariyerinin son noktası olarak kabul edilmektedir. Bu uygulama öğretimi dönemi, teoriyi öğretim üyelerinin gözetiminde uygulamaya geçirme zamanı olarak hizmet eder. Bu çalışmada asıl amaç, mevcut öğretimin bazı sınırlamalarının üstesinden gelmek üzere yeniden tasarlanan uygulama öğretimi programı ile ilgili gözetmenlerin ve öğretmen adaylarının görüşlerini incelemektir. İkinci bir amaç olarak, öğretmen adaylarının öz yansımaları ile son dönemde belirli bir uygulama oturumunda gözetmenler tarafından sağlanan geri bildirimler arasındaki ortaklıklar ve farklılıklar da araştırılmıştır. Veri toplamak için, dil öğretiminde uzmanlaşmakta olan altı öğretmen adayı ve iki öğretim üyesi bu amaçlar doğrultusunda geliştirilen iki farklı yazılı ankete cevap vermek üzere görevlendirilmiştir. Yazılı yanıtlar içerik analizi ve açık kodlama ile analiz edilmiştir. Sonuçlar hem öğretmen adaylarının hem de gözetmenlerin yeniden tasarlanan programın uygulama ve geri bildirim oturumlarına ayrılan zaman gibi birçok güçlü yönü olduğunu düşündüğünü göstermiştir. Bununla birlikte, sadece son yılda aktif uygulama öğretiminin bu yeni programın zayıflığı olduğuna da inanıyorlar. Öğretmen adaylarının uygulamalı öğretimi sonrası yazılı belgelerin incelenmesi öğretmen adaylarının eğitimleri boyunca büyük bir yansıtıcı perspektif kazandıklarını göstermiştir. Ayrıca, malzemelerin kullanımı, yöntemlerin planlanması ve kullanımı konusunda gözetmenlerden yansımalarında ve geri bildirimlerinde bazı farklılıklar vardır. Bu çalışmanın dil öğretmeni eğitim programları ve öğretmen eğitmenleri üzerinde belirgin etkileri vardır.
\end{abstract}

Anahtar Sözcükler: Uygulama ögretimi, ögretmen adaylarl, öğretmen gözetmenleri, ögretmen ĕgitimi 


\section{Introduction}

As a result of the demographic changes in the world and more specifically in the east and southeast region of our country, Turkey, new graduate teachers have to educate students with various backgrounds that are mostly different from their own. Especially with the increasing number of minority students in the country, preservice teachers need to be well-prepared for teaching diverse learners with the awareness and knowledge of teaching multicultural learners. Additionally, it is also known that many preservice teachers come to class with little or no knowledge of how to teach under such conditions. Recent studies indicate that course content and pedagogy have to be linked to field experience and "interwoven with multicultural course work to foster the aims of culturally responsive teaching" (Vavrus, 2002, p. 96). In order to prevent teacher failure, burnout and attrition resulting from this situation and lack of practice teaching experience, the academics in the English Language Teaching department redesigned the current practice teaching program.

The properties of practice teaching have been discussed in the field. Especially about the early start of teaching experience has received great attention. To exemplify, Pease (1995) indicates that early field experience impact preservice teachers in a positive way. Moreover, it is stated that preservice teachers who are provided with early field experiences with diverse groups of learners become more willing to teach these groups (Coballes-Vega, 1992; Burns, Grande and Marable, 2008). In a similar sense, Heinemann, Obi, Pegano and Weiner (1992) reported that the earlier preservice teachers gain field experience, the greater personal teaching efficacy, flexibility and awareness they demonstrate. Additionally, Zeichner (1995) insists that while deciding on the properties of the practice teaching, the length, who supervises it, and where it will take place should be considered. Feiman-Nemser and Buchman (1985) also argue that following three questions need to be asked about the role of practice teaching in learning to teach; (a) What is the preservice teacher learning in the here and now about being a teacher, about pupils, classrooms, and the activities of teaching?, (b) How do these lessons of experience relate to the central purpose of teaching-helping pupils learn?, (c) To what extent do these lessons of experience foster the students' capacity to learn from future experience? 
Therefore, to be able to respond to above questions, practice teaching should be viewed as an important opportunity for teacher learning instead of being a time period to demonstrate the things previously learned. In a parallel view, Goodlad (1990) states that preservice teachers learn how to handle teaching in a classroom all alone, thus, they should be provided with repeated occasions to experience rather than practicing teaching in one classroom under the supervision of one teacher/academic. In addition to all these ideas and properties, during practice teaching preservice teachers' awareness regarding the significance of continuous professional development. In other words, preservice teachers should learn some strategies, such as action research and reflection, for this specific purpose. Dewey (1934) earlier in the previous century, suggested that no matter what teacher educators do to prepare preservice teachers for teaching, they can only prepare them to start teaching. He concludes in his good old article that unless teacher education programs equip preservice teachers with the necessary knowledge and awareness for their own professional development to continue learning which requires continuous education, it is miseducative. In this line, it is a common belief that practice teaching should be formed with strong emphasis on development of preservice teachers in terms of both proficiency in teaching and awareness of continuous professional development. The underlying idea of all these discussions is the belief that "knowledge of teaching differs from knowledge about teaching. Whereas it might be possible to learn about teaching in theoretical courses, the knowledge of teaching, the professional content knowledge of teachers (Shulman, 1987) can only be acquired by active engagement in teaching" (cited in Smith and Lev-Ari, 2005).

Various forms of practice teaching have been suggested in the literature (Buchberger and Busch, 1988); however, three major conceptual approaches have been fore fronted; (1) the apprenticeship, (2) applied science, and (3) inquiry-oriented practice teaching (Zeichner, 1996). In the apprenticeship approach requires preservice teachers spend their time in schools observing an experienced model before engaging in their own practical experience. With the application of applied science approach, the length of the practice teaching decreases. Being the most common approach, the theory of teaching is studied, and then preservice teachers gradually get engaged in teaching by implementing the theory into practice. Recently, the inquiry-oriented model has been favored and put into action. While teacher education takes place in schools, preservice teachers are required to be inquirers and encouraged to reflect on their experiences with the support of supervisors and cooperating teachers in the process. 
Therefore, they learn to take the responsibility of their own learning through inquiry and they also become reflective practitioners by being in such a period (Schon, 1983). Today, teacher education is less commonly viewed as a pure applied science (Eisner, 2002); instead many teacher education programs combine the applied science and the inquiry-oriented approach.

With these ideas in mind, the former practice teaching model suggested by Higher Education Council was redesigned. The former one has been offered as a course in the last year of teacher education program in both semesters for six hours a week. It has been planned to allow preservice teachers practice teaching at least four times under the supervision of the mentor teacher in each semester. As it is clear, this former program is based on only applied science model. That's why, the teacher educators in the department decided to redesign this former model by applying the combination of all the three approaches defined previously; apprenticeship, applied science and inquiry-based approach. In this combined model, as has been suggested in the literature, preservice teachers are required to observe as many experienced teachers as possible to form a kind of schema in their minds for the ideal language teacher in their first year which can be called as the application of the apprenticeship model. With this approach, they start their experience only by doing weekly observations in language classes with diverse group of learners without teaching. They are also provided with the opportunity to engage in the school culture, observe the hardships and strategies applied by different language teachers. During this period, they are required to take field notes, and discuss their experience with peers and the supervisors in-class weekly. In the second and third year of the program, these preservice teachers continue their observations in a more guided way. They are required to do their observations depending on the theory they are instructed in the department. Even though they are not asked to practice teaching officially, they teach unofficially (e.g. pre-teaching, doing an activity etc.). In some exceptional cases, the teachers at cooperating schools can be asking them to substitute when needed. In this sense, applied science approach starts to be used. And in the last year of their teacher education program, they are engaged in the official practice teaching program offered by Higher Education Council which is expected in the form of applied science approach. However, with the awareness of the significance of developing a disposition and capability to teach them take responsibility for their own professional development every student is required to conduct an action research on a problem they have observed. They also start writing self-reflections after each practice 
teaching session in the third and the fourth year. Therefore, this redesigned program also applies inquiry-based approach together with the action research and self-reflections.

The objectives of this redesigned program can be listed as follows; (a) engaging preservice teachers in field experience from the very beginning of the teacher education program, (b) gaining them with experience in different aspects of teacher education (i.e. classroom management, rapport with students, teaching strategies and approaches, materials use, presentation and instruction techniques, and testing), (c) helping them to become reflective practitioners who can apply what they learn during their education and who can take the control of their own professional development, (d) raising their awareness about the professional development through strategies such as action research and reflective practice.

In this study, the purpose is twofold; (a) how preservice teachers and university supervisors view redesigned practice teaching program and (b) how both parties view a specific practice teaching session.

\section{Methodology}

\section{Settings and Participants}

This research was conducted in an ELT department of a foundation university in the south-east part of Turkey. As it was explained previously, the learner profile in this region consists of different minority groups which make the academics consider the situation in planning the components of the language teacher education program. At the time of the study, there were 156 students in the department and 23 of them were senior level students who all engaged in the whole redesigned practice teaching program. Six preservice teachers (two male, four female) and two university supervisors who all completed their practice teaching volunteered to take part in the study. Participating supervisors were the supervisors of the participating preservice teachers.

\section{Data Collection and Analysis}


A qualitative research design was chosen because it allows deep analysis of the text that may not be obtained from survey-based research. In this qualitative study, the data were collected through reflective essays. Reflection is an intentional, dynamic process that allows improvement in one's actions, abilities, and knowledge by learning from experiences (Boud, Keogh \& Walker, 1985). Participating preservice teachers and supervisors were given two different guidelines in the last week of four-year long practice teaching program. In the first one, they were asked to reflect on the weaknesses and strengths of the program as a whole. In the second one, both the preservice teachers and the supervisors were required to reflect on the last teaching practice session. Preservice teachers reflected on their own weaknesses and strengths and supervisors also reflected on the teaching practice of the preservice teachers they observed during their teaching. The guidelines were sent online and the participants were asked to send back the reflective essays the following day online.

Data gathered from reflections were analyzed through open coding strategy. Open coding involves applying codes that are derived from the text (emergent codes) instead of priori codes that are imposed (Strauss \& Corbin, 1998). Essays written by the participants were analyzed for commonly emerging codes by two researchers to meet the inter-rater reliability concern. 93\% agreement was reached. Agreed codes were accepted and the disagreed ones were negotiated. Differing ideas were also discussed.

\section{Trustworthiness of Qualitative Data}

In order to ensure the reliability and validity of the qualitative data gathered from interviews and essays, trustworthiness criteria proposed by Guba and Lincoln (1985) were used. This evaluation was done according to four criteria they suggested; credibility, transferability, dependability and confirmability. To ensure the credibility of the qualitative data, background qualifications and experience of the researcher and member checks were used as suggested techniques by Guba and Lincoln (1985). To ensure transferability, thick description was the suggested technique. By providing description of context in which the study was conducted and the participants, the results of the study can be transferred to similar contexts. The research design, its implementation, the data collection procedures and the analysis were all explained in a very detailed way to accomplish dependability. To ensure the confirmability of the data, 
thick description of the program with all documents and the post facto notes of the researcher helped. And the results approved the reliability of the data.

\section{Ethical Issues}

The ethical committee permission is not required in this study since the data were gathered before 2020 .

\section{Results}

The essays written by the supervisors and the preservice teachers were analyzed for the investigation of the first purpose of the study which is about preservice teachers' and university supervisors' views regarding the redesigned practice teaching program as a whole. In the following table common codes are provided (see table 1). As can be seen, both supervisors and preservice teachers agreed on some weaknesses (i.e. practicing teaching only in the last year, quality of feedback received from cooperating teachers), and strengths (time allocated to practice teaching, guided observations, class discussions, continuous feedback sessions and peer feedback) of this redesigned program. On the other hand, each party mentioned some other strengths and weaknesses. For instance, supervisors think that reflective essays written by the preservice teachers is a strength but preservice teachers think the contrary. Additionally, even though the preservice teachers agree with the supervisors about the importance of peer feedback, they are not happy with the quality of feedback given. The same is applicable for the feedback provided by the cooperating teachers. Some other weaknesses are also explained. As for the supervisors, lack of conversation with cooperating teachers and school administrators and the documentation procedures they need to complete cause some weaknesses. Preservice teachers, on the other hand, consider the timing of the feedback, receiving oral feedback and the quality of cooperating teachers' feedback as other weaknesses.

\section{Table 1}

Codes regarding Practice Teaching Program

\begin{tabular}{llll}
\hline & Supervisors & \multicolumn{2}{c}{ Preservice Teachers } \\
\hline Strengths & Weaknesses & Strengths & Weaknesses \\
\hline Early start & $\begin{array}{l}\text { Practicing teaching only } \\
\text { in the last year }\end{array}$ & Early Start $(\mathrm{N}=6)$ & $\begin{array}{l}\text { Practicing teaching } \\
\text { officially only in the last } \\
\end{array}$ \\
& & year(N=3)
\end{tabular}




\begin{tabular}{|c|c|c|c|}
\hline Guided observation & & $\begin{array}{l}\text { Guided observation } \\
(\mathrm{N}=4)\end{array}$ & $\begin{array}{l}\text { Oral feedback from } \\
\text { supervisors }(\mathrm{N}=5)\end{array}$ \\
\hline Class Discussions & & Class discussions $(\mathrm{N}=4)$ & $\begin{array}{l}\text { Number of class } \\
\text { discussion hours }(\mathrm{N}=6)\end{array}$ \\
\hline \multirow[t]{2}{*}{$\begin{array}{l}\text { Continuous feedback } \\
\text { sessions }\end{array}$} & & $\begin{array}{l}\text { Continuous feedback } \\
\text { sessions }(\mathrm{N}=6)\end{array}$ & Timing of feedback \\
\hline & $\begin{array}{l}\text { Feedback from } \\
\text { cooperating teachers }\end{array}$ & $\begin{array}{l}\text { Feedback from } \\
\text { cooperating teachers } \\
(\mathrm{N}=6)\end{array}$ & $\begin{array}{l}\text { Quality of feedback } \\
\text { received from } \\
\text { cooperating teachers } \\
(\mathrm{N}=6)\end{array}$ \\
\hline \multirow[t]{3}{*}{ Peer feedback } & & Peer feedback $(\mathrm{N}=6)$ & $\begin{array}{l}\text { Quality of peer } \\
\text { feedback }(N=4)\end{array}$ \\
\hline & $\begin{array}{l}\text { Lack of conversation } \\
\text { with cooperating } \\
\text { teachers and school } \\
\text { administrators }\end{array}$ & & \\
\hline & $\begin{array}{l}\text { Documentation } \\
\text { Procedures }\end{array}$ & & \\
\hline
\end{tabular}

Time spent in schools

$(\mathrm{N}=6)$

As can be seen in the above table, both supervisors and the preservice teachers agree that early start of the practice teaching, guided observation in the first two years, discussion done in the class after practice teaching with the teacher trainers, continuous feedback sessions held with the supervisors, peer feedback and writing reflective essays are the strengths of the newly developed practice teaching period. Some sample quotations representing these codes are as follows;

Regarding the advantage of early start one of the supervisors stated that;

"I always believe that the teaching requires intensive experience. So the earlier, the better." (Supervisor A)

In a similar line, one of the preservice teachers declared the following quote;

"I feel lucky because we can start gaining experience from the very beginning. We do not need to wait till the last year as the students in other faculties." (PT B)

In addition, guided observation required preservice teachers to do is accepted as another strength of the program by both groups. 
"Since they start observations in the first year without receiving adequate theory, we need to provide guidance. This helps them understand what to do" (Supervisor $B)$

"Actually, when I was a first grader, I was not that much aware of what to do. So the guiding notes and questions given by our supervisors supported me a lot." (PT D)

Discussion done in the class after practice teaching with the academic supervisor is also accepted as another strength.

"Coming to class with lots of experience and examples to share, they had the chance to discuss and share ideas with us and peers. I believe that it adds a lot to their development." (Supervisor A)

"Class discussions is the only time that we can share ideas, discuss and talk about the models that we observe. The effect of this time period is also very valuable in the last year." (PT B)

Moreover, continuous feedback sessions held with the supervisors considered as one of the strengths.

"We always try to support our students with individual or group feedback after every observation session or practice teaching session. And we always receive great appreciation" (Supervisor, A)

"If there were no feedback sessions, this program would be incomplete. It is the most important piece of this puzzle”. (PT 5)

Peer feedback was also stated among the strengths of the new program by both parties. Following quotations demonstrate feelings of the participants.

"Peers can sometimes act as a mirror. They can be harsh but if they are to the point, their criticism lead to development." (Supervisor B)

"As the peer, I always tried to make constructive criticisms. Because this is what I expect from my peers. We can be more comfortable while giving or receiving feedback from each other compared to our sessions with our supervisors. " (PT 6)

There is also one other strength which was only stated by the preservice teachers; time spent in the schools.

"The total time that we have been pending in schools during our program is nearly 450 hours which is really quite a lot. If we can use this time for our benefit, we can start teaching with great experience compared to our peers in other faculties. " (PT 4) 
On the other hand, writing reflective essays was accepted as a strength by the supervisors, however preservice teachers considered it among the weaknesses for the reasons stated in the following quotations.

"Reflection is one of the basic responsibilities and skills our students develop. We give utmost importance to the improvement of this skill. That's why they are responsible to write reflections after each session in schools". (Supervisor A)

"We are aware that being reflective is very important for our professional development. However, there should be a limit. It loses its importance and turn out to be a burden when we are forced to write a lot." (PT1)

On the contrary to these strengths, both groups agreed on only one weakness; practicing teaching officially only in the last year. Except for this weakness, supervisors stated "feedback given by the cooperating teachers, lack of conversation with cooperating teachers and school administrators and documentation procedures" as the other weaknesses. According to preservice teachers, on the other hand, "oral feedback given by the supervisors, number of inclass discussion hours, timing of feedback, quality of feedback received by the cooperating teachers and the peers" were the weaknesses of the new practice teaching program. Some quotations representing these codes are given below.

One of the supervisors declared her negative feeling regarding the feedback provided by the cooperating teachers as follows;

"Depending on my observation and negotiation with the preservice teachers, cooperating teachers tended to give very limited feedback. They sometimes just said "it was good/bad" without any reasons and suggestions." (Supervisor A)

Supervisors were also not happy with the lack of dialogue with cooperating teachers and school administrators and long and detailed documentation procedures required by the Ministry of Education (MoE).

"There is always a dialogue problem with schools. They are not very open to cooperation. They think that we need them. However, this opportunity can be used for mutual development."

"Ministry of education, cooperating schools and our faculty require us to prepare many files and documents which is very much time consuming. We actually prefer to give feedback to our students instead." 
When the weaknesses stated by the preservice teachers were considered, it is obvious that they are not very much happy with the "type" and "quality" of the feedback received by the supervisors, cooperating teachers and peers.

"We always received detailed feedback, however, our supervisors preferred to give oral feedback. If it was in a written for, it would be more permanent and we could go back and check our progress." (PT 4)

"I prefer to receive feedback right after my practice teaching or even in the following week. If it is given much later, I could forget or my supervisor could forget some details." (PT1)

"I cannot say that we received effective feedback from cooperating teachers. They were always very busy, or just did not want to spend time for feedback." (PT3)

They also felt that the number of class hours when they had the chance to discuss and share their practice teaching experiences with supervisors and peers is very few.

"Starting from the very beginning of our program, we are given chance to discuss what we have done in the classrooms that we were assigned. However, sometimes, it was not enough. It was only two hours and we were 12 students. I mean, every student could only talk nearly 5-10 minutes" (PT 2)

As the second objective of the research, participating preservice teachers were asked to reflect on their last practice teaching session and the supervisors gave their feedbacks on the teaching of these preservice teachers in the written form. The analysis of these documents revealed some common and different codes (see table 2). As can be seen in the following table, the reflections of preservice teachers and the feedback supervisors provided right after the last practice teaching session revealed three common strengths of the preservice teachers; lesson planning skills, classroom management skills and communication with students. On the contrary, even though supervisors considered following lesson plan as one of the strengths, preservice teachers believed it is weakness to follow the lesson plan strictly. The weaknesses stated by the supervisors mentioned in their feedbacks are related to their pedagogical/content knowledge such as pronunciation and giving directions.

Table 2.

Codes about the Views of Supervisors and Preservice Teachers about the Last Practice Teaching Session

\begin{tabular}{llll}
\hline & Supervisors & \multicolumn{2}{c}{ Preservice Teachers } \\
\hline Strengths & Weaknesses & Strengths & Weaknesses \\
\hline Lesson Planning & Pronunciation & Lesson Planning $(\mathrm{N}=6)$ &
\end{tabular}




\begin{tabular}{|c|c|c|c|}
\hline Following Lesson plan & Giving directions & & $\begin{array}{l}\text { Necessity to follow } \\
\text { lesson plan strictly } \\
(\mathrm{N}=4)\end{array}$ \\
\hline $\begin{array}{l}\text { Communication with } \\
\text { students }\end{array}$ & & $\begin{array}{l}\text { Communication with } \\
\text { students }(\mathrm{N}=4)\end{array}$ & $\begin{array}{l}\text { Controlling emotions } \\
(\mathrm{N}=5)\end{array}$ \\
\hline Classroom management & & $\begin{array}{l}\text { Classroom Management } \\
(\mathrm{N}=6)\end{array}$ & \\
\hline
\end{tabular}

Regarding lesson planning the ideas of both groups can be seen in the following quotations.

"It is a skill that we observe generally in experienced teachers. Planning a lesson with the activities, approaches and techniques requires some experience. I am glad that they managed to prepare a well-organized plan". (Supervisor A)

"It is the most time consuming part of my practice. I really worked hard in this planning stage. When I start to follow it in the class and saw that everything was going smooth, I felt really comfortable and happy." (PT 5)

As the other strengths of the preservice teachers, both of the groups agreed on their skills to manage the classroom and communicate with students.

"The atmosphere in the class was very stress-free, all the students were on task. This is mostly because of the good relationship with students." (Supervisor A)

"The rapport I have with students encouraged me in the class. I chose the topics according to their interest on purpose. And we all had fun." (PT4)

"It is fact that, managing a class requires a lot of experience and good teaching skills. I am really happy to see that the plan was implemented without any management problems." (Supervisor B)

"Thanks to the experience we gained throughout the program, we had the chance to observe and apply different management strategies till this session. I mean, we had the chance to practice, try and learn. I do not have difficulty in deciding what to do when a problem occurs." (PT 2)

The weaknesses stated by participants were different. To illustrate, despite the supervisors' consideration of following lesson plan as one of the strengths, preservice teachers believed it is weakness to follow the lesson plan strictly.

"We suggest our students to follow the plan during their practice teaching and novice years. Reflection on action requires some time and experience and if they cannot make good changes, both the students and they can be affected negatively." (Supervisor A) 
"Despite having a well-planned lesson plan, sometimes I wanted to add some extra activities but because of the anxiety of being graded, I could not do it. This caused a little demotivation". (PT 1)

Supervisors thought that preservice teachers' pronunciation skill and their skill to give directions during activities had to be improved.

"Unfortunately, the pronunciation of our students sometimes caused communication to breakdown in the classroom. It is one of the urgent problems they need to overcome." (Supervisor B).

"It is clear that they generally have difficulty in simplifying the language while giving directions." (Supervisor A)

As a final weakness, participating preservice teachers stated that they had difficulty in controlling their emotions.

"I knew that I was going to be graded during and after my teaching by both the cooperating teacher and the supervisor. This situation caused great nervousness and sometimes I had difficulty in controlling my emotions and focusing on the lesson." (PT 3)

\section{Discussion and Conclusion}

In this study, first of all it was aimed to explore the ideas of supervisors and preservice teachers about the redesigned practice teaching program according to the suggested approaches in the field. Also, the common and contrary views of both parties regarding the last practice teaching session which can be accepted as the demonstration of the practice teaching experience gained throughout the four-year long teacher education program were investigated through reflective essays.

In the redesigned program some problems and criticisms declared by the preservice teachers and teacher educators in education faculties were tried to overcome. The criticisms were mainly about the late start of the practice, limited number of observation hours, not spending enough time to discuss on the observed issues and teaching experience. Taking all these concerns into consideration, practice teaching period was formulated to start from the very beginning of the teacher education program. As a result, preservice teachers in the program started their practice in the first year by doing observations. As Pease (1995) indicated, both participating groups appreciated this situation in their writings. And when they reflected on the last practice teaching 
session, they indicated that, improved communication and classroom management skills of preservice teachers were mainly because of this feature of the redesigned program. Therefore, this result supported many results of various research in the field (e.g. Pease, 1995; Heinemann, Obi, Pegano \& Weiner and Bookart, 1997). Moreover, the length was also significant in terms of providing enough opportunity to the preservice teachers to help them learn about management skills as Goodlad (1990) stated. Another necessity for the improvement of these skills is providing repeated occasions for adequate experience instead of practicing teaching in few classrooms with only one supervisor and one cooperating teacher. It is for sure that the more models they observe, the more experience they gain, the more strategies and approaches they try, the better teacher candidates with improved teaching skills they become. In order to achieve this purpose, preservice teachers got engaged in apprenticeship approach in the first and second years. And in the third and fourth years, the same group started to implement applied science (gradually getting engaged in teaching by implementing the theory into practice) and inquiry-oriented (research to find solutions to the problems in the classroom) approach. As a result, both groups of participants indicated lesson planning skills, management skills, communication skills as strengths after the practice teaching session. Moreover, the preservice teachers indicated "the need to follow the lesson plan strictly" as a weakness which means that they are skilled enough to reflect in and on action and take the control of their own teaching. This expertise is obviously the result of inquiry-based approach by the help of which they learned how to develop professionally. Continuous reflection of the preservice teachers and the class discussions were also believed to be effective to improve teaching skills (Zeichner, 1996). However, the number of reflective essays that the preservice teachers were required to write were indicated as a burden by the preservice teachers. This shows that the real aim of this task could have been managed better if the number was less. Furthermore, the preservice teachers stated their positive ideas about the feedback sessions with supervisors. However, they desire to receive feedback in a written form as well to be able to remember and check their progress in future. This awareness and consciousness of these participants indicate their agency to take responsibility for their own professional development. However, the reality about the time limitations of supervisors prevent them from giving written feedback to some extent. Despite not being directly related to the content of the newly developed program, another point mentioned especially by the supervisors is the lack of communication with cooperating teachers and schools. Moreover, supervisors complained about documentation procedures of practicum period which requires time and energy. However, due to the 
requirements of Ministry of education and higher education council, documents such as the progress report, official payment documents, attendance lists should be kept by the supervisors.

To conclude, the study showed that, the redesigned program helped overcome the problems (e.g. late start of the practice, limited number of observation hours, not spending enough time to discuss on the observed issues and teaching experience) generally shared in the field. The length, the tasks, unguided and guided observations, creating more opportunities for practice teaching were appreciated by both parties. Moreover, being engaged in reflective action research cycle in the last year of the program, helped them to become reflective practitioners who can take the responsibility of their own profession. However the results also showed that, despite the increased amount, in order to help preservice teachers learn control their emotions and become real reflective teachers, the number of teaching hours should be increased and the number of reflection essays should be decreased and assigned in a more planned way. As a final point, preservice teachers stated that being graded affected their decision making skills and controlling emotions negatively. In order to overcome this problem, self-evaluation and peer evaluation and formative assessment will be considered.

\section{Implications}

This study has some significant implications for language teacher education, higher education council, ministry of education, schools and school administrations. To begin with, teacher educators in the education faculties should consider the complaints and criticisms of their students and try to take action to help them become well-prepared practitioners before they start their career. This is important to prevent the attrition and burnout rates which is very high in the first a few years of the teaching profession.

Secondly, the results of this study can act as a guide for the higher education council to revise the practicum period of the education faculties. They can officially plan, design and offer a better program by taking the results of this study into consideration.

Finally, the dialogue between the schools and universities is very valuable and significant to improve the quality of teaching and to connect theory and practice. That is to say, schools and administrations should be informed about the expectations in detail by the faculties. Their 
awareness should be raised about the significance of this process for the future of preservice teachers with the weekly or monthly meetings.

\section{Limitations and Suggestions for Further Research}

As many case studies have, this study also has some limitations such as lack of generalizability. Due to the limited number of participants in only one setting, the results may not be generalizable to other contexts. Additionally, by being only qualitative, the results may not be robust. So, triangulating the qualitative findings with other quantitative sources can increase the reliability of the findings. Therefore, further research is suggested to overcome these limitations. In other words, the number of data tools can be increased and same study can be conducted in various settings for generalizability.

\section{Statements of ethics and conflict of interest}

"I, as the Corresponding Author, declare and undertake that in the study titled as "Views of Prospective Teachers and Supervisors on a Practicum Program: A Case Study”, scientific, ethical and citation rules were followed; Turkish Online Journal of Qualitative Inquiry Journal Editorial Board has no responsibility for all ethical violations to be encountered, that all responsibility belongs to the author/s and that this study has not been sent to any other academic publication platform for evaluation. "

\section{References}

Boud, D., Keogh, R., \& Walker, D. (1985) Reflection: Turning Experience into Learning. London: Kogan Page.

Buchberger, F., \& Busch, F. (1988). The role of the practical element in initial teacher education. European Journal of Teacher Education, 11(1), 5-7.

Burns, B. A., Grande, M., \& Marable, M. A. (2008). Factors influencing teacher candidates' participation in a paid field experience with urban students. Issues in Teacher Education, 17(2), 101-116. 
Coballes-Vega, C. (1992). Considerations in Teaching Culturally Diverse Children. ERIC Digest.

Dewey, J. (1934/1980) Art as Experience (New York, Perigree Books).

Eisner, E. W. (2002). The arts and the creation of mind. Yale University Press.

Heinemann, H., Obi, R. Pagano, A. \& Weiner, L. (1992). Effects of using early pre-service field experiences in urban settings to prepare teachers to meet the challenges of teaching in multicultural urban schools.(ERIC Document Reproduction Service No. ED344868)

Feiman-Nemser, S., \& Buchman, M. (1985). Pitfalls of experience in teacher preparation. Teachers College Record, 87(1), 53-65.

Goodlad, J. I. (1990). Teachers for our nation's schools. Jossey-Bass Inc., Publishers, 350 Sansome St., San Francisco, CA 94104.

Lincoln, Y. S., \& Guba, E. G. (1985). Establishing trustworthiness. Naturalistic inquiry, 289, 331.

Shulman, L. (1987). Knowledge and teaching: Foundations of the new reform. Harvard educational review, 57(1), 1-23.

Schon, D. A. (1983). The reflective practitioner: How professionals think in action. New York, NY: Basic Books.

Schon, D. A. (1987). Educating the reflective practitioner: Towards a new design for teaching and learning in the profession. San Francisco, CA: Jossey-Bass.

Smith, K., \& Lev-Ari, L. (2005). The place of the practicum in pre-service teacher education: The voice of the students. Asia-Pacific Journal of Teacher Education, 33(3), 289-302.

Strauss, A. \& Corbin, J. (1998). Basics of qualitative research, Second edition. Thousand Oakes, CA: Sage Publications.

Vavrus, M. (2002). Transforming the multicultural education of teachers. New York: Teachers College Press.

Zeichner, K. (1996). Currents of reform in preservice teacher education. Teachers College Press, Teachers College, Columbia University, 1234 Amsterdam Avenue, New York, NY 10027 (paperback: ISBN-0-8077-3429-2; clothbound: ISBN-0-8077-3430-6). 